\title{
Biochemical Composition and Morphological Characters of Cooked Indigenous Colored Rice Grown in Assam, India
}

\author{
Tiluttama Mudoi ${ }^{1}$ and Priyanka Das ${ }^{2} *$ \\ ${ }^{1}$ Analytical Chemist, Analytical Laboratory, Coffee Quality Division, Coffee Board, \\ Bengaluru-560001, India \\ ${ }^{2}$ Department of Biochemistry and Agricultural Chemistry, Assam Agricultural University, \\ Jorhat-785013, Assam, India \\ *Corresponding author
}

\section{A B S T R A C T}

\section{Ke y w o r ds \\ colored rice, proximate composition, phenols, antioxidant activity, cooking}

\section{Article Info}

Accepted:

05 April 2020

Available Online:

10 May 2020
A few colored rice varieties of Assam (both brown and 4\% polished) as influenced by cooking were analysed for proximate composition, total phenolic compounds, total flavonoids, antioxidant activities, zinc content and morphological character. The amylose content in cooked rice ranged from $0.02-8.98 \%$. All the brown cooked rice varieties showed decrease in amylose content $(0.004 \%$ in Kenekuabao to $98.13 \%$ in Betu) except 'Negheribao' ( brown rice) than their raw forms. Decrease in amylose content for the polished form of cooked rice varieties was also recorded (31.14\% in Amanabao to 98. 81\% in Rangachakua). Total phenol content (TPC) in cooked brown rice was found in the range of $132.86 \mathrm{mg}$ (in Negheribao) to $368.15 \mathrm{mg}$ (in Rangachakua) catechol equivalents per $100 \mathrm{gm}$ dry sample. The TPC of cooked polished rice also varied from $123.01 \mathrm{mg}$ (in Negheribao) to $296.99 \mathrm{mg}$ (in Amanabao) per $100 \mathrm{gm}$ dry wt. There was loss of phenolic compounds up to $88 \%$ in cooked brown rice (Dal bao) and up to $86.68 \%$ in cooked polished rice (Negheribao) as compared to the same in raw. The elongation ratio (ER) was found to vary from 0.86 (in Kenekua bora) to 1.01 (in Julbao) and 1.13 (in Rongachakua) to 1.57 (in Biroi) for brown rice and polished rice, respectively.

\section{Introduction}

Rice is the most important food crop grown in Assam. The state has its climatic and physiographic features favorable for rice cultivation and the crop is grown in a wide range of agro-ecological situations. This region is endowed with large varieties of rice germplasm with extreme physicochemical properties. The release of high yielding varieties replaces the traditional landraces, which leads to gradual erosion of the rice genetic diversity. The rice varieties commonly have whitish kernels. Rice is generally consumed as white rice with the husk, bran, and germ removed. However, consumption of brown rice (hulled rice) is increasing in recent years, due to the 
increased awareness about its health benefits and good nutritional properties due to higher amounts of proteins, minerals and also phytochemicals (Tan et al., 2009 and Mohan et al., 2010). There are also rice varieties with a colored testa (black, purple, or red), that give slightly colored kernels on milling. It was observed that, colored rice varieties are more nutritious and rich in minerals and possess antioxidant properties (Itani et al., 2002 and Yawadio et al., 2007).

Attention is currently being given to the antioxidative and radical scavenging properties of colored rice cultivars because of their potential to provide and promote human health by reducing the concentration of reactive oxygen species.

We have already reported about the nutritional composition of twenty one traditional colored rice cultivars of Assam, India (Mudoi and Das, 2018) and phytochemicals and mineral content of sixteen indigenous red rice varieties of Assam, India (Mudoi and Das, 2019).

There is no literature available regarding the chemical composition and antioxidant potential of the colored rice varieties grown in Assam after cooking. Therefore, the present study was conducted to explore the colored rice varieties native to Assam with respect to the phytochemicals and antioxidant potentials as affected by cooking.

\section{Materials and Methods}

The varieties, selected based on our earlier study on phytochemical content (Mudoi and Das, 2019), were collected from different regions of Assam during the harvesting periods (Table 1). According to the season and ecology, the diverse varieties are grown such as Baon (deep water rice), Ahu (autumn), and Sali (winter).

\section{Processing of rice grains}

Rice grains were de-husked using a de-husker (Satake Corporation, Hiroshima, Japan) and then polished (4\%) using a polisher (Satake Corporation, Hioroshima, Japan). Bran was removed and was collected separately.

\section{Proximate composition analysis}

Moisture content, crude protein, crude fat and ash content were estimated as per AOAC method, 1995. The total carbohydrate content (including crude fiber content) on dry basis was determined by subtracting the per cent (dry basis) content of crude protein, ash and crude fat from 100. The amylose content was estimated according to Sowbhagya and Bhattacharya, 1979.

\section{Extraction of rice samples for analysis of phytochemicals}

The rice flour $(1.5 \mathrm{~g})$ was weighed accurately and extracted at room temperature with $85 \%$ aqueous methanol $(1: 20 \mathrm{w} / \mathrm{v})$ under agitation using a magnetic stirrer for $30 \mathrm{~min}$. The mixtures were centrifuged at $2500 \mathrm{~g}$ for 10 min and the supernatants were collected. The residues were re-extracted twice under the same conditions, resulting finally in $50 \mathrm{ml}$ crude extract.

\section{Determination of total phenolic content (TPC)}

The TPC of extracts was determined using the Folin-Ciocalteu reagent (Singleton et al., 1999). Catechol was used as standard and TPC was expressed as mg catechol equivalent per $100 \mathrm{~g}$ flour.

\section{Determination of total flavonoid content}

The total flavonoid content was measured by colorimetric method as described previously 
(Wu and $\mathrm{Ng}, 2008$ ). The total flavonoid content was expressed as grams quercetin equivalent $(\mathrm{QE})$ per kg dry wt of sample.

\section{Determination of DPPH radical scavenging activity}

The free radical scavenging activity of extract was measured following a previously reported procedure using the stable 2,2'-diphenyl-1picrylhydrazyl radical (DPPH•) (BrandWilliams et al., 1995). An aliquot of $0.3 \mathrm{~mL}$ of a diluted extract (2 times) was vigorously mixed with $1.5 \mathrm{~mL}$ of freshly prepared $0.004 \%$ DPPH in methanol and held in the dark for $30 \mathrm{~min}$ at room temperature. The absorbance was then read at $517 \mathrm{~nm}$ against blanks. DPPH free radical-scavenging ability was calculated by using the following formula:

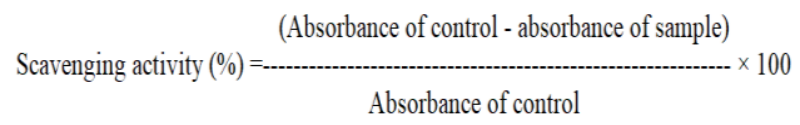

\section{Determination of $\mathrm{Zn}$ content}

The ash obtained was dissolved in dilute $\mathrm{HCl}$ $(1: 1)$ on a water bath at $100^{\circ} \mathrm{C}$ and the mixture was evaporated to dryness. $4 \mathrm{ml}$ of $\mathrm{HCl}$ and 2 $\mathrm{ml}$ of glass distilled water were added, warmed and the acid soluble portion obtained after filtration was made up to $100 \mathrm{ml}$ with glass distilled water. This solution was used for estimation of $\mathrm{Zn}$ in colored rice samples by atomic absorption spectrometer.

\section{Cooking of colored rice}

Thirty gram rice grain of each variety (both brown and polished) was taken in beakers and $54 \mathrm{~mL}$ distilled water $(1: 1.8 \mathrm{w} / \mathrm{v})$ was added to each. After soaking for $30 \mathrm{~min}$ at room temperature $\left(27 \pm 1{ }^{\circ} \mathrm{C}\right)$, the samples were cooked at water bath for $10 \mathrm{~min}$ by open steaming at $100{ }^{\circ} \mathrm{C}$ in the water used for initial soaking.
Complete cooking was indicated by loss of opaque uncooked portions when cooked kernel was pressed between glass slides. After cooking, samples were dried at $50^{\circ} \mathrm{C}$ in a hot air oven till constant weight, cooled and powdered in grinder and stored air tight till further analysis.

\section{Morphological and physical properties of milled rice grain}

Each sample (10 kernels) was cooked in a water bath at $98^{\circ} \mathrm{C}$ for $10 \mathrm{~min}$. The cooked rice was then transferred to a petri dish lined with filter paper. Length and breadth of raw and cooked rice kernels of cultivars were measured by using Vernier caliper. The measurements were repeated 6 times in each sample and thus an average of 6 grains was recorded. Ratio of length and breadth gave $\mathrm{L} / \mathrm{B}$ ratio. The elongation ratio(ER) was calculated using the following formula ER $=$ Average length of cooked rice grains $(\mathrm{mm}) /$ Average length of raw rice grains $(\mathrm{mm})$.

\section{Statistical analysis}

All assays were carried out in triplicate and the results expressed as mean \pm SEM.

\section{Results and Discussion}

\section{The amylose content}

The amylose content of rice is one of the most important criteria of rice quality in terms of cooking and pasting properties. The amylase content of the varieties was found in the range of waxy to intermediate amylase containing group. There was higher amylose content in polished rice samples $(4.21 \%$ in Betu to $21.18 \%$ in Rongachakua) as compared to brown rice $(1.07 \%$ in Betu to $20.98 \%$ in Rongachakua). This might be due to percent increase (amylose is located at the 
endosperm) for loss of bran and aleuron layer during polishing. In the present study, the amylose content (Table 2) in cooked samples ranged from $0.02-8.98 \%$. All the brown cooked rice samples showed decrease in amylose content (maximum 98. 13\% in Betu, to $0.004 \%$ in Kenekuabao,) except 'Negheribao' (brown rice) than their raw forms. The polished form of rice samples showed decrease in amylose content (maximum 98. $81 \%$ in Rangachakua, to $31.14 \%$ in Amanabao). The decrease in amylose content on cooking might be either due to rupture of some of the glycosidic linkages during heating or formation of resistant starch (RS) (Kim et al., 2006). Kavita et al., (1998) found that the RS content of cooked rice was $1.96 \mathrm{~g} / 100 \mathrm{~g}$ DM. When the samples were stored for either 24 or $48 \mathrm{~h}$ at $4^{0} \mathrm{C}$, the $\mathrm{RS}$ contents increased to $3.37 \mathrm{~g}$ and $4.38 \mathrm{~g} / 100 \mathrm{~g}$ DM, respectively. In our study also, the cooked rice after dying was stored at $4^{0} \mathrm{C}$ till analysis.

However, the observed increase in amylose content in 'Negheribao' (brown rice) might be due to rupture of alpha 1-6 linkages of amylopectins. The rupture of glycosidic linkages during processing (prolonged heating) was reported by Svihus et al., 2005. Hydrolysis of starch as a result of heat treatments was also reported by Rehman and Shah, 2005. In addition, the decrease in amylase content might be due to increase in bound water content after cooking, which was not evaporated when the cooked rice was dried before analysis.

\section{Total carbohydrates, crude fat, crude protein and ash content}

The total carbohydrates including crude fibers, crude fat, crude protein and ash content of cooked colored rice varieties of Assam is presented in Table 3. The observed differences among the varieties might be due to genetical differences, and differences in nutrient status of soil, where these were grown. The crude protein was also detected in higher level (more than 10\%, dry basis) in a few varieties (Jul bao and Negheri bao) in brown form. The variety Jul bao (brown rice) also contains higher ash content $(1.85 \%)$, and the lowest value of ash $(0.56 \%)$ was found for Betu (polished rice). There was a significant loss of crude fat, protein and ash in polished rice samples as compared to brown rice. This difference may be attributed to the degree of milling, as milling of rice removes the outer layer of the grain where most of the fats and minerals are concentrated (Thomas et al., 2016). Devi et al., 2015 also observed increase of carbohydrate content and decrease of crude protein, crude fat and ash content with increase of degree of polishing of rice.

Our result on proximate composition of raw form of rice samples are in agreement with those already reported (Devi et al., 2015, Thomas et al., 2016, Das et al., 2018). Murdifin et al., (2015) reported the total contents of ash, fat, protein, crude fiber and carbohydrate of pigmented rice varieties of Indonesia were in the range of 1.19-2.13, 1.06-3.05, 7.24-14.02, 0.66-0.99 and 71.29$77.14 \%$, respectively at less than or equal to $14 \%$ moisture content.

The observed reduction of crude fat, crude protein and ash content of cooked rice samples as compared to respective raw samples might be due to increase of bound moisture content of the dried cooked rice samples. However, the observed increase in some of the samples was not actual increase, only changes in percentage due to change of other parameters.

The same can be justified for the increase in total carbohydrate including the crude fibre content of all the cooked rice samples as it was calculated by subtraction method. Thomas et al., (2016) reported that the cooking of raw rice samples resulted in 
significant reduction in value of crude protein. However, they compared raw rice and freshly cooked rice, without removal of moisture.

A few reports can be traced on analysis of cooked rice for proximate composition on dry weight basis.

\section{Total phenol content (TPC)}

TPC of the investigated rice varieties are presented in Table 4 . The present study shows high phenol content. TPC of brown rice samples ranged from $1136.98 \mathrm{mg}$ (in Betu) to $2223.68 \mathrm{mg}$ (in Amanabao) catechol equivalents per $100 \mathrm{~g}$ rice (dry basis). TPC of polished rice samples ranged from $240.41 \mathrm{mg}$ (in Kenekuabao) to $933.89 \mathrm{mg}$ (in Jul bao) catechol equivalents per $100 \mathrm{~g}$ rice (dry basis). There was loss of TPC in polished samples in comparison their respective brown rice samples.

Total phenol content was decreased in cooked sample as compared to raw. Total phenol content in cooked brown rice was found in the range of $132.86 \mathrm{mg}$ (in Negheribao) to $368.15 \mathrm{mg}$ in (Rangachakua) catechol equivalents per 100 gm dry sample.

The TPC of cooked polished rice also varies from 123.01(in Negheribao) to $296.99 \mathrm{mg}$ (in Amanabao) per 100 gm dry wt. There was loss of phenolic compounds up to $88 \%$ in cooked brown rice sample (Dal bao) and $86.68 \%$ (Negheribao) in cooked polished sample as compared to the same in raw.

\section{Total flavonoid content (TFC)}

TFC of brown rice samples ranged from $387 \mathrm{mg}$ (in Rangachakua) to $1000.75 \mathrm{mg}$ (in Dalbao) quercetin equivalents per $100 \mathrm{~g}$ rice (dry basis). TFC of polished rice samples ranged from $72.60 \mathrm{mg}$ (in Kenekuabao) to $374.46 \mathrm{mg}$ (in Negheribao) quercetin equivalents per $100 \mathrm{~g}$ rice (dry basis). There was loss of TFC in polished samples in comparison their respective brown rice samples.

Total flavonoid content (TFC) in cooked brown rice sample ranged from $81.00 \mathrm{mg}$ (in Dalbao) to $303.82 \mathrm{mg}$ (in Kenekuabao) QE per 100 gm dry wt and in cooked polished rice from $1.75 \mathrm{mg}$ (in Biroi) to $112.68 \mathrm{mg}$ (in Amanabao) QE per 100 gm dry wt.

It was observed that the total phenolic and flavonoid content decreased drastically on cooking when compared to the respective raw samples. The drastic decrease in TPC and TFC could be due to thermal degradation of phenol and flavonoid compounds (Chmiel et al., 2018).

\section{DPPH free radical scavenging activity}

DPPH free radical scavenging activity in brown rice sample ranged from $81.54 \%$ (in Betu) to $96.00 \%$ (in Negheribao). In polished rice sample, DPPH activity varied from $73.74 \%$ (in Betu) to $86.35 \%$ (in Kenekuabao). DPPH activity is also decreased in cooked samples than raw ones.

DPPH free radical scavenging activity in cooked brown rice and polished rice samples varies from $42.78 \%$ (in Dalbao)-79.23\% (in Kenekuabao) and 32.06 (in Biroi) $-51.86 \%$ (in Negheribao). Study on the determination of phenolic compounds in different parts of rice grain confirmed that phenolic acids in bran ensure the highest contribution to the total phenolic content in the grain compared to endosperm and embryo (Shao and Bao, 2015; Shao et al., 2014).

Hence, bran removal process during polishing of dehulled rice to obtain milled rice, the form that is generally consumed, reduces the concentration of phenolic compounds in the grain. Chmiel et al., 2018 reported that the level of total polyphenols in unpolished grains was 3.5-fold higher than in polished ones and 
the brown rice showed the highest TAA(total antioxidant activity) and phenolic content $(622.5 \mathrm{mg} / \mathrm{kg}$ dry weight or $62.5 \mathrm{mg} / 100 \mathrm{gm}$ dry matter). Murdifin et al., (2015) reported that the anthocyanin and phenolic contents of black glutinous rice extracts from some pigmented varieties of Indonesia were in the range of 94.70-202.46 mg Cy-3-glc/100 g db and 292.74-746.25 mg GAE/100 g db, respectively, which were higher than the black rice (66.08-113.83 mg Cy-3-glc/100 g $\mathrm{db}$ and 119.74-230.10 $\mathrm{mg}$ GAE /100 g db) and the red rice $(0-12.85 \mathrm{mg} \mathrm{Cy}-3-\mathrm{glc} / 100 \mathrm{~g}$ $\mathrm{db}$ and 12.52-64.52 $\mathrm{mg} \mathrm{GAE} / 100 \mathrm{~g}$. $\mathrm{db}$ ) and they found that the antioxidant activity was positively correlated with total phenolic and anthocyanin compounds.

Massaretto et al., 2011 reported that the cooking was found to reduce the average content of total phenolics in the pigmented group by about $50 \%$ (from 409.7 to $202.6 \mathrm{mg}$ FA eq./100 g). The average content of soluble phenolics in pigmented rice dropped by $83 \%$ after cooking (from 335.3 to $57.9 \mathrm{mg}$ ferrulic acid eq./100 g), indicating that the soluble phenolic fraction, mainly composed of proanthocyanidins, was the most affected by the thermal treatment. Chmiel et al., 2018 reported that among three processing methods, cooking using rice cooker caused the highest reduction of phenolic content (29$31 \%$ ), followed by microwaving (18-33\%), and boiling (18-28\%). However, as observed by Chmiel et al., 2018, the absorption of all the cooking water by the rice during thermal treatment in our study indicated that decrease of AA is most likely related to the thermal and oxidative degradation of phenolic compounds.

\section{Zn content after cooking}

Generally, pigmented rice has the highest mineral content compared to non-pigmented rice (Hurtada et al., 2018). $\mathrm{Zn}$ is highly concentrated in rice embryo and uniformly distributed in bran layer and endosperm (Liang et al., 2008). Liu et al., 2019 observed decrease in some of the minerals including zinc after cooking which involved washing and soaking prior to cooking and they suggested that decrease was mainly due to washing step. The reduced mineral content by washing was mainly related to the mineral distribution in rice grains and rice morphology (large length-to-width ratio). In our study, Zn content decreased in cooked samples as compared to their respective raw samples. In cooked brown rice, $\mathrm{Zn}$ content varied from $1.31 \mathrm{mg}$ (in Amanabao) to 2.15 mg (Negheribao)per 100 gm dry wt whereas, it varied in raw brown rice samples from $2.42 \mathrm{mg}$ (in Amanabao) to $10.63 \mathrm{mg}$ (in Hurupibao) per $100 \mathrm{gm}$.

It was reported (Neelamraju et al., 2012) that in 'Madhukar' and 'Jalmagna', two deepwater rice varieties of India, the grain zinc concentration ranged from 0.4 to $104 \mathrm{ppm}$ ( or 0.04 to $10.4 \mathrm{mg}$ per $100 \mathrm{gm})$. Cooking generally leads to reduction in mineral content of food samples due to leaching of the minerals into the cooking water or due to increase of moisture content (Thomas et al., 2016). Although, in the present analysis, sample was not washed and cooking water was not allowed to leach out and the result was also expressed on dry weight basis, the decrease in zinc content can be justified considering increase of bound water content during cooking, which was not evaporated during drying after cooking.

Morphological character of raw and cooked colored rice varieties of Assam

Morphological character of raw and cooked colored rice varieties of Assam are presented at the Table 6 . For the raw form of brown and polished varieties, the L/B ratio ranged from 1.82 (in Jul bao) to 2.85 (in Rongachakua) and 1.75 (in Dalbao) to 2.80 (in Biroi), respectively. 
Table.1 Description of indigenous colored rice varieties collected from different regions of Assam

\begin{tabular}{|r|l|l|c|}
\hline SI No & Name of varieties & Place of collection & Type of rice \\
\hline $\mathbf{1}$ & Amana bao & North Lakhimpur, Assam & deep water \\
\hline $\mathbf{2}$ & Hurupi bao & North Lakhimpur, Assam & deep water \\
\hline $\mathbf{3}$ & Dal bao & North Lakhimpur, Assam & deep water \\
\hline $\mathbf{4}$ & Biroi & North Lakhimpur, Assam & winter \\
\hline $\mathbf{5}$ & Kenkuabao & North Lakhimpur, Assam & deep water \\
\hline $\mathbf{6}$ & Betu & Majuli, Assam, Assam & autumn \\
\hline $\mathbf{7}$ & Negheribao & North Lakhimpur, Assam & deep water \\
\hline $\mathbf{8}$ & Jul bao & North Lakhimpur, Assam & deep water \\
\hline $\mathbf{9}$ & Rongachokua & North Lakhimpur, Assam & autumn \\
\hline
\end{tabular}

Table.2 The amylose content of raw* and cooked colored rice

\begin{tabular}{|c|c|c|c|c|c|c|}
\hline \multirow[t]{2}{*}{$\begin{array}{l}\text { SI } \\
\text { No }\end{array}$} & \multirow[t]{2}{*}{$\begin{array}{l}\text { Name of } \\
\text { variety }\end{array}$} & \multirow[t]{2}{*}{ Form } & \multicolumn{2}{|c|}{$\begin{array}{l}\text { Amylose content } \\
(\%, \text { dry basis })\end{array}$} & \multicolumn{2}{|c|}{$\%$ change due to cooking } \\
\hline & & & $\begin{array}{l}\text { Brown } \\
\text { rice }\end{array}$ & $\begin{array}{l}\text { Polished } \\
\text { rice }\end{array}$ & Brown rice & $\begin{array}{c}\text { Polished } \\
\text { rice }\end{array}$ \\
\hline \multirow[t]{2}{*}{1} & Jul Bao & Raw & $8.85 \pm 0.11$ & $9.55 \pm 0.15$ & -64.18 & -80.41 \\
\hline & & Cooked & $3.17 \pm 0.14$ & $1.87 \pm 0.06$ & & \\
\hline \multirow[t]{2}{*}{2} & Dal bao & Raw & $11.78 \pm 0.15$ & $12.98 \pm 0.10$ & -97.87 & -87.75 \\
\hline & & Cooked & $0.25 \pm 0.07$ & $1.59 \pm 0.07$ & & \\
\hline \multirow[t]{2}{*}{3} & Biroi & Raw & $9.92 \pm 0.03$ & $13.15 \pm 0.13$ & -86.89 & -81.90 \\
\hline & & Cooked & $1.30 \pm 0.23$ & $2.38 \pm 0.15$ & & \\
\hline \multirow[t]{2}{*}{4} & Hurupibao & Raw & $5.74 \pm 0.59$ & $13.36 \pm 0.41$ & -64.11 & -68.70 \\
\hline & & Cooked & $2.06 \pm 0.07$ & $4.25 \pm 0.26$ & & \\
\hline \multirow[t]{2}{*}{5} & Negheribao & Raw & $4.61 \pm 0.35$ & $10.17 \pm 0.59$ & +48.66 & -95.96 \\
\hline & & Cooked & $8.98 \pm 0.25$ & $0.41 \pm 0.05$ & & \\
\hline \multirow[t]{2}{*}{6} & Kenkuabao & Raw & $2.22 \pm 0.07$ & $16.42 \pm 0.34$ & -0.004 & -77.71 \\
\hline & & Cooked & $2.21 \pm 0.08$ & $3.66 \pm 0.08$ & & \\
\hline \multirow[t]{2}{*}{7} & Betu & Raw & $1.07 \pm 0.02$ & $4.21 \pm 0.07$ & -98.13 & -57.24 \\
\hline & & Cooked & $0.02 \pm 0.01$ & $1.80 \pm 0.04$ & & \\
\hline \multirow[t]{2}{*}{8} & Amana bao & Raw & $12.29 \pm 0.11$ & $12.36 \pm 0.06$ & -95.85 & -31.14 \\
\hline & & Cooked & $0.51 \pm 0.01$ & $8.51 \pm 0.18$ & & \\
\hline \multirow[t]{2}{*}{9} & Rongasokua & Raw & $20.98 \pm 0.22$ & $21.18 \pm 0.14$ & -94.47 & -98.81 \\
\hline & & Cooked & $1.16 \pm 0.05$ & $0.25 \pm 0.02$ & & \\
\hline
\end{tabular}

*Mudoi and Das, 2018 
Table.3 The total carbohydrates (including fibre), crude fat, crude protein and ash content (\%, dry basis) of raw* and cooked colored rice

\begin{tabular}{|c|c|c|c|c|c|c|}
\hline $\begin{array}{l}\text { SI } \\
\text { No }\end{array}$ & Name of variety & Form & $\begin{array}{c}\text { Total } \\
\text { carbohydrates }\end{array}$ & Crude fat & Crude protein & Ash \\
\hline \multirow[t]{2}{*}{1} & $\begin{array}{l}\text { Jul bao } \\
\text { brown rice }\end{array}$ & Raw & $80.62 \pm 0.28$ & $3.70 \pm 0.11$ & $13.83 \pm 0.35$ & $1.85 \pm 0.05$ \\
\hline & & Cooked & $86.61 \pm 0.17$ & $3.10 \pm 0.08$ & $8.69 \pm 0.56$ & $1.60 \pm 0.07$ \\
\hline \multirow[t]{2}{*}{2} & $\begin{array}{l}\text { Jul bao } \\
\text { polished rice }\end{array}$ & Raw & $88.15 \pm 0.50$ & $3.25 \pm 0.02$ & $7.35 \pm 0.33$ & $1.25 \pm 0.09$ \\
\hline & & Cooked & $88.00 \pm 0.54$ & $1.25 \pm 0.06$ & $9.29 \pm 0.18$ & $1.46 \pm 0.25$ \\
\hline \multirow[t]{2}{*}{3} & Negheribao brown rice & Raw & $85.13 \pm 0.20$ & $3.10 \pm 0.11$ & $10.03 \pm 0.10$ & $1.74 \pm 0.13$ \\
\hline & & Cooked & $87.58 \pm 0.40$ & $2.09 \pm 0.05$ & $8.4 \pm 0.27$ & $1.93 \pm 0.32$ \\
\hline \multirow[t]{2}{*}{4} & Negheribao polished rice & Raw & $87.85 \pm 0.27$ & $1.55 \pm 0.12$ & $9.35 \pm 0.32$ & $1.25 \pm 0.10$ \\
\hline & & Cooked & $88.36 \pm 0.11$ & $0.73 \pm 0.05$ & $9.61 \pm 0.45$ & $1.30 \pm 0.07$ \\
\hline \multirow[t]{2}{*}{5} & $\begin{array}{l}\text { Hurupibao } \\
\text { brown rice }\end{array}$ & Raw & $87.96 \pm 0.69$ & $3.83 \pm 0.10$ & $6.91 \pm 0.35$ & $1.30 \pm 0.07$ \\
\hline & & Cooked & $92.93 \pm 0.68$ & $1.99 \pm 0.09$ & $3.56 \pm 0.24$ & $1.52 \pm 0.21$ \\
\hline 6 & Hurupibao polished rice & $\begin{array}{c}\text { Raw } \\
\text { cooked }\end{array}$ & $\begin{array}{l}89.06 \pm 0.57 \\
91.65 \pm 0.53\end{array}$ & $\begin{array}{l}2.23 \pm 0.10 \\
0.74 \pm 0.09\end{array}$ & $\begin{array}{l}7.56 \pm 0.42 \\
7.03 \pm 0.13\end{array}$ & $\begin{array}{l}0.70 \pm 0.07 \\
0.58 \pm 0.07\end{array}$ \\
\hline \multirow[t]{2}{*}{7} & $\begin{array}{l}\text { Dal bao } \\
\text { brown rice }\end{array}$ & Raw & $88.09 \pm 0.20$ & $3.1 \pm 0.11$ & $7.54 \pm 0.24$ & $1.27 \pm 0.07$ \\
\hline & & Cooked & $86.31 \pm 0.57$ & $2.64 \pm 0.07$ & $9.62 \pm 0.36$ & $1.43 \pm 0.09$ \\
\hline \multirow[t]{2}{*}{8} & $\begin{array}{l}\text { Dal bao } \\
\text { polished rice }\end{array}$ & Raw & $89.76 \pm 0.15$ & $1.4 \pm 0.07$ & $8.18 \pm 0.20$ & $0.66 \pm 0.07$ \\
\hline & & Cooked & $90.7 \pm 0.57$ & $0.52 \pm 0.08$ & $8.05 \pm 0.12$ & $0.73 \pm 0.04$ \\
\hline \multirow[t]{2}{*}{9} & $\begin{array}{l}\text { Biroi } \\
\text { brown rice }\end{array}$ & Raw & $87.37 \pm 0.53$ & $3.6 \pm 0.04$ & $7.81 \pm 0.35$ & $1.22 \pm 0.13$ \\
\hline & & Cooked & $85.34 \pm 0.16$ & $3.08 \pm 0.07$ & $9.82 \pm 0.42$ & $1.76 \pm 0.12$ \\
\hline \multirow[t]{2}{*}{10} & $\begin{array}{l}\text { Biroi } \\
\text { polished rice }\end{array}$ & Raw & $88.55 \pm 0.36$ & $1.11 \pm 0.06$ & $9.60 \pm 0.22$ & $0.74 \pm 0.04$ \\
\hline & & Cooked & $89.05 \pm 0.03$ & $0.33 \pm 0.07$ & $9.73 \pm 0.11$ & $0.89 \pm 0.07$ \\
\hline \multirow[t]{2}{*}{11} & Rongasokua brown rice & Raw & $88.45 \pm 0.22$ & $3.20 \pm 0.11$ & $7.00 \pm 0.42$ & $1.35 \pm 0.16$ \\
\hline & & Cooked & $88.31 \pm 0.24$ & $2.79 \pm 0.13$ & $7.62 \pm 0.35$ & $1.28 \pm 0.12$ \\
\hline \multirow[t]{2}{*}{12} & Rongasokua polished rice & Raw & $91.77 \pm 0.40$ & $1.70 \pm 0.14$ & $5.78 \pm 0.20$ & $0.75 \pm 0.06$ \\
\hline & & Cooked & $90.39 \pm 0.27$ & $1.89 \pm 0.09$ & $6.61 \pm 0.20$ & $1.11 \pm 0.06$ \\
\hline \multirow[t]{2}{*}{13} & Amana bao brown rice & Raw & $88.53 \pm 0.18$ & $3.60 \pm 0.59$ & $6.44 \pm 0.26$ & $1.43 \pm 0.10$ \\
\hline & & Cooked & $88.88 \pm 0.71$ & $2.80 \pm 0.09$ & $6.71 \pm 0.13$ & $1.61 \pm 0.12$ \\
\hline \multirow[t]{2}{*}{14} & Amana bao polished rice & Raw & $89.24 \pm 0.55$ & $2.20 \pm 0.19$ & $7.05 \pm 0.05$ & $1.51 \pm 0.06$ \\
\hline & & Cooked & $88.98 \pm 0.71$ & $1.68 \pm 0.14$ & $7.83 \pm 0.42$ & $1.51 \pm 0.17$ \\
\hline \multirow[t]{2}{*}{15} & Kenkuabao brown rice & Raw & $87.54 \pm 0.55$ & $2.18 \pm 0.01$ & $8.97 \pm 0.36$ & $1.31 \pm 0.06$ \\
\hline & & Cooked & $87.51 \pm 0.27$ & $2.17 \pm 0.04$ & $9.03 \pm 0.10$ & $1.29 \pm 0.08$ \\
\hline \multirow[t]{2}{*}{16} & Kenkuabao polished rice & Raw & $89.65 \pm 0.62$ & $1.12 \pm 0.05$ & $8.65 \pm 0.47$ & $0.58 \pm 0.07$ \\
\hline & & Cooked & $91.35 \pm 0.32$ & $0.52 \pm 0.04$ & $7.50 \pm 0.27$ & $0.63 \pm 0.04$ \\
\hline \multirow[t]{2}{*}{17} & $\begin{array}{l}\text { Betu } \\
\text { brown rice }\end{array}$ & Raw & $90.48 \pm 0.34$ & $2.77 \pm 0.15$ & $6.02 \pm 0.10$ & $0.73 \pm 0.08$ \\
\hline & & Cooked & $90.11 \pm 0.23$ & $0.89 \pm 0.07$ & $8.34 \pm 0.17$ & $0.66 \pm 0.09$ \\
\hline \multirow[t]{2}{*}{18} & $\begin{array}{l}\text { Betu } \\
\text { polished rice }\end{array}$ & Raw & $92.44 \pm 0.70$ & $1.40 \pm 0.18$ & $5.6 \pm 0.31$ & $0.56 \pm 0.08$ \\
\hline & & Cooked & $90.79 \pm 0.41$ & $0.77 \pm 0.07$ & $7.94 \pm 0.46$ & $0.50 \pm 0.07$ \\
\hline
\end{tabular}

*Mudoi and Das, 2018 
Table.4 Total phenol content, flavonoid content and \% DPPH Inhibition of raw* and cooked colored rice varieties of Assam

\begin{tabular}{|c|c|c|c|c|c|c|c|c|}
\hline \multirow[t]{2}{*}{$\begin{array}{l}\text { Sl } \\
\text { No }\end{array}$} & \multirow[t]{2}{*}{$\begin{array}{l}\text { Name of } \\
\text { variety }\end{array}$} & \multirow[t]{2}{*}{ Form } & \multicolumn{2}{|c|}{$\begin{array}{c}\text { Total phenol } \\
\text { content } \\
\text { (mg catechol } \\
\text { equivalents per } 100 \mathrm{~g} \text { ) }\end{array}$} & \multicolumn{2}{|c|}{$\begin{array}{c}\text { Total flavonoid content } \\
\text { (mg quercetin equivalents per } \\
100 \text { gm dry wt) }\end{array}$} & \multicolumn{2}{|c|}{ \% DPPH Inhibition } \\
\hline & & & $\begin{array}{c}\text { Brown } \\
\text { rice }\end{array}$ & $\begin{array}{l}\text { Polished } \\
\text { rice }\end{array}$ & Brown rice & $\begin{array}{l}\text { Polished } \\
\text { rice }\end{array}$ & Brown rice & $\begin{array}{l}\text { Polished } \\
\text { rice }\end{array}$ \\
\hline \multirow[t]{2}{*}{1} & Jul Bao & Raw & $1145.06 \pm 33.59$ & $933.89 \pm 34.12$ & $466.10 \pm 67.93$ & $248.58 \pm 58.36$ & $82.62 \pm 0.42$ & $82.96 \pm 0.20$ \\
\hline & & Cooked & $323.39 \pm 18.59$ & $240.79 \pm 10.36$ & $99.48 \pm 7.70$ & $67.28 \pm 6.31$ & $43.02 \pm 0.53$ & $40.93 \pm 0.16$ \\
\hline \multirow[t]{2}{*}{2} & Dal bao & Raw & $2215.73 \pm 67.50$ & $263.50 \pm 7.12$ & $1000.75 \pm 86.93$ & $73.62 \pm 18.19$ & $94.63 \pm 0.05$ & $82.33 \pm 1.77$ \\
\hline & & Cooked & $264.04 \pm 8.62$ & $220.37 \pm 3.32$ & $81.00 \pm 2.75$ & $48.74 \pm 2.72$ & $42.78 \pm 0.51$ & $37.70 \pm 0.20$ \\
\hline \multirow[t]{2}{*}{3} & Biroi & Raw & $1462.27 \pm 56.58$ & $289.19 \pm 17.25$ & $495.14 \pm 40.74$ & $137.92 \pm 12.90$ & $95.57 \pm 0.14$ & $84.23 \pm 0.16$ \\
\hline & & Cooked & $245.49 \pm 5.80$ & $246.63 \pm 5.85$ & $85.94 \pm 8.84$ & $1.75 \pm 0.12$ & $43.31 \pm 0.12$ & $32.06 \pm 0.23$ \\
\hline \multirow[t]{2}{*}{4} & Hurupibao & Raw & $1283.23 \pm 47.89$ & $542.66 \pm 20.97$ & $443.65 \pm 25.47$ & $82.59 \pm 0.89$ & $84.65 \pm 3.14$ & $84.14 \pm 0.00$ \\
\hline & & Cooked & $292.81 \pm 0.0$ & $205.16 \pm 5.01$ & $86.59 \pm 7.28$ & $33.79 \pm 6.54$ & $43.45 \pm 0.08$ & $38.45 \pm 0.08$ \\
\hline \multirow[t]{2}{*}{5} & Negheribao & Raw & $1740.38 \pm 87.51$ & $924.51 \pm 93.63$ & $617.05 \pm 20.08$ & $374.46 \pm 2.05$ & $96.00 \pm 0.26$ & $82.37 \pm 0.24$ \\
\hline & & Cooked & $132.86 \pm 2.40$ & $123.01 \pm 2.34$ & $140.69 \pm 0.00$ & $20.31 \pm 0.51$ & $58.24 \pm 0.21$ & $51.86 \pm 0.08$ \\
\hline \multirow[t]{2}{*}{6} & Kenkuabao & Raw & $1711.13 \pm 127.35$ & $240.41 \pm 5.49$ & $517.50 \pm 15.96$ & $72.60 \pm 0.00$ & $94.82 \pm 0.34$ & $86.35 \pm 3.88$ \\
\hline & & Cooked & $290.67 \pm 4.93$ & $134.28 \pm 2.53$ & $303.82 \pm 3.20$ & $58.15 \pm 2.74$ & $79.23 \pm 5.51$ & $51.65 \pm 0.67$ \\
\hline \multirow[t]{2}{*}{7} & Betu & Raw & $1136.98 \pm 53.68$ & $462.37 \pm 6.56$ & $478.10 \pm 41.53$ & $146.33 \pm 6.13$ & $81.54 \pm 0.23$ & $73.74 \pm 2.29$ \\
\hline & & Cooked & $337.60 \pm 8.82$ & $194.67 \pm 7.27$ & $221.46 \pm 5.74$ & $41.63 \pm 25.57$ & $60.06 \pm 0.20$ & $44.20 \pm 0.08$ \\
\hline \multirow[t]{2}{*}{8} & Amana bao & Raw & $2223.68 \pm 33.48$ & $547.03 \pm 25.09$ & $766.65 \pm 11.45$ & $216.84 \pm 2.07$ & $92.80 \pm 2.05$ & $82.05 \pm 0.36$ \\
\hline & & Cooked & $349.25 \pm 2.27$ & $296.99 \pm 6.36$ & $207.04 \pm 3.92$ & $112.68 \pm 1.48$ & $54.42 \pm 0.08$ & $50.41 \pm 0.16$ \\
\hline \multirow[t]{2}{*}{9} & Rongasokua & Raw & $1534.52 \pm 143.45$ & $247.18 \pm 1.19$ & $387 \pm 23.15$ & $80.97 \pm 35.37$ & $83.07 \pm 0.09$ & $83.38 \pm 0.40$ \\
\hline & & Cooked & $368.15 \pm 3.18$ & $132.71 \pm 19.09$ & $212.86 \pm 3.88$ & $26.77 \pm 2.19$ & $57.08 \pm 0.08$ & $41.46 \pm 0.49$ \\
\hline
\end{tabular}

*Mudoi and Das, 2019 
Table.5 Zn content of raw (brown)* and cooked colored rice varieties of Assam

*Mudoi and Das, 2019

\begin{tabular}{|l|c|c|}
\hline \multicolumn{1}{|c|}{ Varieties } & Form & mg/100g dry wt \\
\hline \multirow{2}{*}{ Amana bao } & Raw & $2.42 \pm 0.21$ \\
\hline \multirow{2}{*}{ Nongasokua } & cooked & $1.31 \pm 0.07$ \\
\hline \multirow{2}{*}{ Biroi } & Raw & $9.99 \pm 0.36$ \\
\hline \multirow{2}{*}{ Betu } & cooked & $1.32 \pm 0.07$ \\
\hline \multirow{2}{*}{ Hurupibao } & Raw & $6.01 \pm 0.09$ \\
\hline \multirow{2}{*}{ Dal bao } & cooked & $2.15 \pm 0.04$ \\
\hline \multirow{2}{*}{ Kenkua bao } & cooked & $6.31 \pm 0.14$ \\
\hline \multirow{2}{*}{ Jul bao } & Raw & $1.83 \pm 0.21$ \\
\hline \multirow{2}{*}{ cooked } & $5.34 \pm 0.16$ \\
\hline & Raw & $1.45 \pm 0.14$ \\
\hline
\end{tabular}

Table.6 Morphological characters of colored rice of Assam before and after cooking

\begin{tabular}{|c|c|c|c|c|c|c|c|}
\hline \multirow[t]{2}{*}{ varieties } & \multicolumn{3}{|c|}{ Before cooking } & \multicolumn{4}{|c|}{ After cooking } \\
\hline & $\begin{array}{l}\text { Length } \\
(\mathrm{L}, \mathrm{mm})\end{array}$ & $(\mathrm{B}, \mathrm{mm})$ & $\begin{array}{l}\mathrm{L} / \mathrm{B} \\
\text { Ratio }\end{array}$ & $(\mathrm{L}, \mathrm{mm})$ & $(\mathrm{B}, \mathrm{mm})$ & $\begin{array}{l}\mathrm{L} / \mathrm{B} \\
\text { Ratio }\end{array}$ & ER \\
\hline $\begin{array}{l}\text { Dal bao } \\
\text { brown rice }\end{array}$ & $6.02 \pm 0.01$ & $2.74 \pm 0.18$ & 2.19 & $5.5 \pm 0.19$ & $2.83 \pm 0.12$ & 1.94 & 0.91 \\
\hline $\begin{array}{l}\text { Dal bao } \\
\text { polished rice }\end{array}$ & $5.04 \pm 0.01$ & $2.88 \pm 0.17$ & 1.75 & $6.25 \pm 0.19$ & $3.16 \pm 0.12$ & 1.97 & 1.24 \\
\hline $\begin{array}{l}\text { Biroi } \\
\text { brown rice }\end{array}$ & $6.21 \pm 0.19$ & $2.53 \pm 0.04$ & 2.40 & $6.17 \pm 0.34$ & $3.16 \pm 0.12$ & 1.90 & 0.99 \\
\hline $\begin{array}{l}\text { Biroi } \\
\text { polished rice }\end{array}$ & $5.73 \pm 0.18$ & $2.04 \pm 0.01$ & 2.80 & $9.0 \pm 0.28$ & $2.00 \pm 0.00$ & 4.50 & 1.57 \\
\hline $\begin{array}{l}\text { kenkua bora } \\
\text { brown rice }\end{array}$ & $6.55 \pm 0.00$ & $3.013 \pm 0.004$ & 2.17 & $5.67 \pm 0.23$ & $3.08 \pm 0.09$ & 1.84 & 0.86 \\
\hline Kenkua bora polished rice & $6.64 \pm 0.39$ & $3.03 \pm 0.008$ & 2.19 & $6.42 \pm 0.46$ & $2.58 \pm 0.22$ & 2.48 & 0.96 \\
\hline $\begin{array}{l}\text { Jul bao } \\
\text { brown rice }\end{array}$ & $5.51 \pm 0.004$ & $3.02 \pm 0.01$ & 1.82 & $5.58 \pm 0.22$ & $3.00 \pm 0.00$ & 1.86 & 1.01 \\
\hline $\begin{array}{l}\text { Jul bao } \\
\text { polished rice }\end{array}$ & $5.06 \pm 0.03$ & $2.8 \pm 0.25$ & 1.8 & $6.5 \pm 0.24$ & $3.08 \pm 0.22$ & 1.86 & 1.28 \\
\hline $\begin{array}{l}\text { Rongasokua } \\
\text { brown rice }\end{array}$ & $6.00 \pm 0.00$ & $2.10 \pm 0.00$ & 2.85 & $5.83 \pm 0.34$ & $3.50 \pm 0.24$ & 1.66 & 0.97 \\
\hline Rongasokua polished rice & $6.51 \pm 0.01$ & $2.95 \pm 0.16$ & 2.20 & $7.33 \pm 0.36$ & $3.00 \pm 0.00$ & 2.44 & 1.13 \\
\hline $\begin{array}{l}\text { Amana bao } \\
\text { brown rice }\end{array}$ & $6.54 \pm 0.016$ & $3.00 \pm 0.00$ & 2.18 & $6.02 \pm 0.48$ & $3.83 \pm 0.18$ & 1.57 & 0.92 \\
\hline Amana bao polished rice & $5.78 \pm 0.11$ & $3.03 \pm 0.01$ & 1.90 & $6.83 \pm 0.34$ & $3.00 \pm 0.00$ & 2.27 & 1.18 \\
\hline $\begin{array}{l}\text { Negheri bao } \\
\text { brown rice }\end{array}$ & $6.27 \pm 0.17$ & $3.01 \pm 0.01$ & 2.08 & $5.83 \pm 0.34$ & $3.25 \pm 0.19$ & 1.79 & 0.92 \\
\hline Negheri bao polished rice & $6.02 \pm 0.004$ & $3.03 \pm 3.03$ & 1.98 & $7.5 \pm 0.245$ & $3 \pm 0.00$ & 2.5 & 1.25 \\
\hline $\begin{array}{l}\text { Kenkua bao } \\
\text { brown rice }\end{array}$ & $6.59 \pm 0.34$ & $2.86 \pm 0.25$ & 2.3 & $5.83 \pm 0.34$ & $3 \pm 0.00$ & 1.94 & 0.88 \\
\hline Kenkua bao polished rice & $6.03 \pm 0.04$ & $2.79 \pm 0.18$ & 2.16 & $8.75 \pm 0.34$ & $2.83 \pm 0.18$ & 3.09 & 1.45 \\
\hline $\begin{array}{l}\text { Hurupi bao } \\
\text { brown rice }\end{array}$ & $7.02 \pm 0.004$ & $3.01 \pm 0.01$ & 2.33 & $6.25 \pm 0.18$ & $3.08 \pm 0.29$ & 2.02 & 0.89 \\
\hline Hurupi bao polished rice & $7.01 \pm 0.01$ & $2.71 \pm 0.19$ & 2.58 & $8.67 \pm 0.34$ & $3.00 \pm 0.00$ & 2.89 & 1.24 \\
\hline
\end{tabular}


After cooking, the same changed to 1.57 (in Amana bao) to 2.02 (in Hurupibao) and 1.86 (in Julbao) to 4.5 (in Biroi). After cooking, there was decrease of $\mathrm{L} / \mathrm{B}$ ratio for brown rice and the reverse was for polished rice. Yadav et al., 2007 reported that the length and breadth of milled raw rice varied from 5.85 to $8.25 \mathrm{~mm}$ and 1.65 to $2.93 \mathrm{~mm}$, respectively. Murdifin et al., (2015) reported that thirteen of pigmented rice (PR) varieties had no significant differences in the length and $\mathrm{L} / \mathrm{B}$ ratio.

The PR length was in the range of 5.60-6.82 $\mathrm{mm}$. The $\mathrm{L} / \mathrm{B}$ ratio was in the range of 2.22 2.90 indicating that all rice had medium shape (between slender and bold). The ER was found to vary from 0.86 (in Kenekua bora) to 1.01 (in Julbao) for brown rice and 1.13 (in Rongachakua) to 1.57 (in Biroi) polished rice respectively. Shahidullah et al., 2009 stated that higher ER is preferred than lower ER for quality of cooked rice.

It was observed that open cooking without allowing the loss of cooking/ soaking water, caused a decrease of crude fat, amylose and zinc content and increase in the total carbohydrate. Cooking probably caused percent changes in crude protein, ash and zinc content, not actual change, which might be due to increase of bound water after cooking. Moreover, there was decrease of total phenols, flavonoids and antioxidant activities after cooking.

The prominent varieties for cooking as indicated by the present research are Negheribao (brown) and Amanabao (polished) regarding amylose content $(8.98 \%$ and $8.51 \%$, respectively), Julbao (polished), Negheribao ((polished), Dalbao (brown), Biroi (both brown and polished) regarding crude protein content (more than 9\%), Rongachakua, Betu, kenekuabao (all brown), Amanabao, Julbao, Biroi, Dalbao,
Hurupibao, (both brown and polished regarding total phenol content ( more than $200 \mathrm{mg}$ catechol equivalent/ 100gm), Negheri bao, Biroi and Dalbao (all brown forms) regarding higher zinc content (more than $1.5 \mathrm{mg} / 100 \mathrm{gm}$ DM), and Biroi, Kenekuabao, Julbao, Negheribao (all polished form) regarding morphological character (ER more than 1.25).

\section{Acknowledgement}

The first author is grateful to Department of Biotechnology, Ministry of Science and Technology, Govt of India for offering her DBT Research Associate ship and funding to carry the project work.

\section{References}

AOAC, Association of Official Analytical Chemists.1995. (sixteenth ed.). Washington, D.C.

Brand-williams, W., Cuvelier, M.E. andBerset, C. (1995). Use of free radical method to evaluate antioxidant activity. Lebensmittel Wissenschaft and Technologie. 28: 25-30.

Chmiel T, Saputro IE, Kusznierewicz B,Bartoszek A. (2018). The impact of cooking method on the phenolic composition, total antioxidant activity and starch digestibility of rice (Oryza sativaL.). J Food Process Preserv. 42:e13383.

Das,P.; Singha, A.D.; Goswami, K. and Sarmah, K. (2018). Detection of Nutritionally Significant Indigenous Rice Varieties from Assam, India. Bull. Env. Pharmacol. Life Sci. 7(4): 59-64.

Devi, G.N., Padmavathi, G., Ravindra Babu, V. and Waghray, K. (2015). Proximate Nutritional Evaluation of Rice (Oryza Sativa L.). Journal of Rice Research .8 (1):23-32.

Hurtada, W. A., Barrion, A. S. A. and 
Nguyen-Orca, M. F. R. (2018). Mineral content of dehulled and well-milled pigmented and non-pigmented rice varieties in the Philippines. International Food Research Journal 25(5): 2063-2067.

Itani, T., Tamaki, M., Arai, E., and Horino, T.(2002). Distribution of amylose, nitrogen, and minerals in rice kernels with various characters. Journal of Agricultural and Food Chemistry. 50: 5326-5332.

KavitaV,Verghese S, Chitra GR, Prakash J (1998) Effects of processing, storage time and temperature on the resistant starch of foods. Journal of Food Science and Technology 35, 299-304.

Kim, J. C. ; Mullan, B. P. ; Hampson, D. J. and Pluske, V. (2006). Effects of amylose content, autoclaving, parboiling, extrusion, and post-cooking treatments on resistant starch content of different rice cultivars. Australian Journal of Agricultural Research, 2006, 57, 1291-1296.

Liang, J., Li, Z., Tsuji, K., Nakano, K., Nout, M. J. R., \& Hamer, R. J. (2008). Milling characteristics and distribution of phytic acid and zinc in long-, medium- and shortgrain rice. Journal of Cereal Science, 48(1), 83-91.

Liu, K, Zheng, J, , Wang. X., Chena, F. (2019). Effects of household cooking processes on mineral, vitamin $\mathrm{B}$, and phytic acid contents and mineral bioaccessibility. Food Chemistry. 280 :59-64

Massaretto , I.L., Alves, M.F.M., Mira, N.V.M. Carmona, A.K. and Marquez, U.M.L. (2011). Phenolic compounds in raw and cooked rice (Oryza sativa L.) and their inhibitory effect on the activity of angiotensin I-converting enzyme. Journal of Cereal Science, 54: 236-240.

Mohan, B. H., Malleshi, N.G. and Koseki, T.(2010).Physic-Chemical
Characteristics and Non-Starch Polysaccharide Contents of Indica and Japonica Brown Rice and Their Malts. Food Science and Technology, , 43(5), 784-791.

Mudoi, T. and Das, P. (2018). Nutritional composition of traditional colored rice cultivars of Assam, India. Bull. Env. Pharmacol. Life Sci. 7(7): 10- 14.

Mudoi, T. and Das, P. (2019). A Study on Phytochemicals and Mineral Content of Indigenous

Murdifin, M., Pakki, E., Rahim, A. Syaiful, S. Ismail, A., Evary, Y.M. and Bahar, A.M. (2015). Physicochemical Properties of Indonesian Pigmented Rice (Oryza sativa Linn.) Varieties from South Sulawesi. Asian Journal of Plant Sciences 14 (2): 59-65.

Neelamraju, S., Mallikarjuna Swamy, B. P., Kaladhar, K., Anuradha, K., Venkateshwar Rao, Y., Batchu, A. K., Agarwal, S., Babu, A. P., Sudhakar, T., Sreenu, K., Longvah, T., Surekha, K., Rao, K. V., Ashoka Reddy, G., Roja, T. V., Kiranmayi, S. L., Radhika, K., Manorama, K., Cheralu, C. and Viraktamath, B. C. (2012) Increasing iron and zinc in rice grains using deep water rices and wild species-identifying genomic segments and candidate genes. Quality Assurance and Safety of Crops \& Foods, 4(3): 138.

Red Rice of Assam, India. Int.J.Curr.Microbiol.App.Sci 8(4): 1-12.

Rehman, Z. and Shah, W. H. (2005). Thermal heat processing effects on antinutrients, protein and starch digestibility of food legumes. Food. Chem. 91: 327-33

Shahidullah, S.M. , Hanafi, M. M., Ashrafuzzaman, M., Ismail, M. R. and Khair, A. ( 2009). Genetic diversity in grain quality and nutrition of aromatic rices. African Journal of Biotechnology. 8 (7):1238-1246.

Shao, Y., and Bao, J. (2015). Polyphenols in 
whole rice grain: Genetic diversity and health benefits. Food Chemistry, 180: 86-97.

Shao, Y., Xu, F., Sun, X., Bao, J., \& Beta, T. (2014). Identification and quantification of phenolic acids and anthocyanins as antioxidants in bran, embryo and endosperm of white, red and black rice kernels (Oryza sativa L.). Journal of Cereal Science, 59: 211-218.

Singleton, V. L., Orthofer, R., LamuelaRaventos, R. M. (1999). Analysis of total phenols and other oxidation substrates and antioxidants by means of Folin-Ciocalteu reagent. Meth. Enzymol. 299: 152-178.

Sowbahagya, C.M.; Bhattacharya, K.R. (1979). Simplified determination of amylase in milled rice. Starch-Starke, 31, 159-163.

Svihus, B.; Uhlen, A. K. and Harstad, O. M. (2005). Effect of starch granule structure, associated components and processing on nutritive value of cereal starch: A review. Animal. Feed. Sci. Technol. 122: 303-320.

Tan, F., Dai, W. and Hsu, K. 2009. Changes in Gelatinization and Rheological Characteristics of Japonica Rice Starch
Induced by Pressure/Heat Combinations. Journal of Cereal Science. 49(2): 285-289.

Thomas, A.O.; Olayinka, A.; and Kayode, A. (2006). Comparative Study of Nutrient composition and Retention of Raw and Cooked Imported and Local Rice (Oryza sativa) Varieties. British Journal of Applied Science \& Technology 16(2): 1-9.

$\mathrm{Wu}, \mathrm{S}$. J. and $\mathrm{Ng}$, L.T. (2008). Antioxidant and free radical scavenging activities of wild bitter melon (Momordica charantia Linn. var. abbreviateSer.) in Taiwan. LWT-Food Sci. Technol. 41: 323-330.

Yadav, R.B., Khatkar, B.S. and Yadav, B.S. (2007). Morphological, physicochemical and cooking properties of some Indian rice (Oryza sativa L.) cultivars. Journal of Agricultural Technology 3(2): 203-210.

Yawadio, R., Tanimori, S., Morita, N. 2007. Identification of phenolic compounds isolated from pigmented rices and their aldose reductase inhibitory activities. Food Chemistry. 101(4): 1616-1625.

\section{How to cite this article:}

Tiluttama Mudoi and Priyanka Das. 2020. Biochemical Composition and Morphological Characters of Cooked Indigenous Colored Rice Grown in Assam, India. Int.J.Curr.Microbiol.App.Sci. 9(05): 402-414. doi: https://doi.org/10.20546/ijcmas.2020.905.045 